Volume 1, Number 1, 2015

\title{
Fuzzy Identification of Technological Objects
}

\author{
Mykhailo Horbiychuk, Taras Humeniuk ${ }^{*}$, Dmytro Povarchuk \\ Ivano-Frankisk National Technical University of Oil and Gas, \\ 15 Karpatska Str., Ivano-Frankivsk, 76019, Ukraine
}

(C) 2015 Authors. Published by Lviv Polytechnic National University.

Received: March 19,2015. Revised: April 15,2015. Accepted: May 19, 2015.

\section{Summary}

In practice, information on statistical characteristics of series mode interference is available only in certain cases. Moreover, for this or that reason input variables are measured inexactly, and their values can be specified with some uncertainty. The identification task is significantly complicated when the measuring signal passes through a natural channel with unknown statistical characteristics. This is, for instance, the case with well drilling when axial weight on the drilling bit and drilling bit rotations per minute are gauged by above-ground devices. The study resulted in developing a method of building polynomial empirical models for a case when input factors are fuzzy variables with known Gaussian membership functions. The output variable of the model was shown to be also a fuzzy variable in such conditions; the corresponding membership function on the basis of which the identification task is formulated was obtained. To determine the parameters of the model with fuzzy input factors, the least square method was applied, which allowed obtaining a respective formula incorporating the information on input factors fuzziness.

Keywords: model; polynomial relationship; membership function; fuzzy numbers; method; model parameters.

\section{Introduction}

Empirical models are conventionally developed using the least square method, which makes it possible to describe a relationship between a certain set of physical quantities. This relationship can be obtained as a result of a theoretical study or an experiment. Should a mathematical model result from theoretical reasoning, it reflects relationships between a certain set of factors in the analytical form only within the accuracy of some parameters. If a mathematical model is developed on the experimental basis, the model structure is often postulated. In both cases, data on the object under study should be used for creating a model, which would allow making conclusions on the accuracy of the model's representation of the real object.

\section{Review of contemporary publications}

In its general statement, the problem of describing empirical relationship using parametric regression suggests that the specified function is identified within the accuracy of some parameters which are selected in order that a particular criterion of approximation between experimental and respective calculated data has a minimum value.

Such classical statement of the identification problem assumes that the structure of the model is known, and it is often chosen to be linear with respect to the model parameters.

\footnotetext{
${ }^{*}$ Corresponding Author. E-mail address: tarasksm@gmail.com
} 
The other way of developing empirical models supposes that the model structure is unknown [1], and therefore an external criterion is used to select it. This approach to empirical model creation resulted in two methods. The first one is known as group method of data handling (GMDH) [2], [7]. The other one was denominated combinatorial method [3] selecting the best model by searching through the whole set of models which can be created from the polynomial model.

Inductive method of models self-organization is implemented in stages, the first one being generation of candidate models in a certain order of complexity and the second one selection of the best model according to a selection criterion [3].

There are two major ways of generating candidate models.

The first way is combinatorial method, which selects models out of a more general one by assigning zero value to some coefficients of its equation. As a result, a set of models is obtained. The best model is selected on the basis of one of the selection criteria [3].

The drawback of combinatorial method of model selection is the need to sort out a large number of models. If an $m$-degree polynomial is chosen as a base model, the total number of candidate models amounts to $2^{M}-1$, where $M$ is the total number of terms in the complete $m$-degree polynomial. Even modern ECMs are not capable of implementing such algorithms for a large number of variables and high degree of the polynomial. GMDH produces models which feature intermediate variables for every selection set, which significantly complicates transfer to the input variables of the system being simulated.

Out of the two methods, combinatorial method is more viable, since it allows obtaining a model in which the arguments are input variables of the system. To eliminate the problem of large dimension, the genetic approach was suggested [4].

When implementing these methods, it is assumed that exact values of physical quantities being the system variables are known. Apparently, such an assumption somewhat idealizes the conditions of observation of the operating object, since any physical quantity is measured with a certain error, this entailing the need to take into account the effect of measurement errors on the accuracy of empirical models [5].

Information on distribution laws and statistical characteristics of measurement channels is hardly available, as engineering practice shows. Typically, one can specify a range to which a measured value of a certain physical quantity belongs. In such cases a specific value of a measured quantity should be considered as a fuzzy value, which necessitates development of methods taking aboard fuzziness of input data [6].

The research aims at developing a method of identifying technological objects on condition that experimental data used for construction of empirical models are fuzzy values.

\section{Discussion of the major outcomes}

The object under consideration has $m$ inputs $x_{i}, i=\overline{1, m}$ and one output $y$. The relationship $y=f(\bar{x})$, where $\bar{x}=\left(x_{1}, x_{2}, \ldots, x_{m}\right)^{T}$, will be sought in the form of regression dependence

$$
y=\sum_{j=0}^{n} c_{j} \prod_{i=1}^{m} x_{i}^{\varphi_{j i}}
$$

where $c_{j}$ are polynomial coefficients; $\varphi_{j i}$ are degrees of the arguments which are to satisfy the following constraint:

$$
\sum_{i=1}^{m} \varphi_{j i} \leq r, \forall j
$$


The number of terms $n$ in polynomial (1) is determined using the formula below [1]:

$$
n=\frac{(m+r) !}{m ! r !}
$$

If variables $x_{i}, i=\overline{1, m}$ are measured error-free and the value of $y$ is affected by series mode interference with normal law of distribution, parameters of this law are invariable for all observation points. In this case, to determine the parameters of model (1) the least square method can be used. If variances of series mode interference are known but differ in different observation points, the generalized least square method is applicable.

In practice, information on statistical characteristics of series mode interference is available only in some cases. Besides, for various reasons input variables are measured inexactly, and their values can be specified with some uncertainty. The identification task becomes fairly complicated when the measuring signal passes through a natural channel with unknown statistical characteristics. For instance, this occurs in well drilling when axial weight on the drilling bit and drilling bit rotations per minute are gauged by above-ground instruments.

In such cases input variables $x_{i}, i=\overline{1, m}$ can be naturally interpreted as fuzzy variables with the membership function as follows:

$$
\mu\left(x_{i}\right)=\exp \left(-\frac{\left(x_{i}-x_{i}^{(0)}\right)^{2}}{2 \alpha_{x i}^{2}}\right)
$$

where $x_{i}^{(0)}, \alpha_{i}, i=\overline{1, m}$ are mode value and fuzziness parameter of membership function, respectively.

Membership function of the input variable can be defined as

$$
\mu(y)=\mu\left(\sum_{j=1}^{n} c_{j} \prod_{i=1}^{m} x_{i}^{\varphi_{j i}}\right)=\exp \left(-\frac{\left(y-a_{y}\right)^{2}}{2 \alpha_{y}^{2}}\right) .
$$

Parameters $a_{y}$ and $\alpha_{y}$ of membership function (3) are determined using rules of arithmetic for $(L-R)$ type fuzzy numbers in Gaussian-basis sets [8,9].

Based on the structure of model (1), determination of parameters $a_{y}$ and $\alpha_{y}$ of the membership function (4) requires such operations with fuzzy numbers as addition and multiplication of fuzzy numbers, and multiplication of a fuzzy number by an exact one.

Let $A_{L R}=\left\langle a_{1}, \alpha_{1}, \beta_{1}\right\rangle$ and $B_{L R}=\left\langle a_{2}, \alpha_{2}, \beta_{2}\right\rangle$ be $(L-R)$ type fuzzy numbers, where $a_{1}, a_{2}$ are mode values; $\alpha_{1}, \alpha_{2}, \beta_{1}, \beta_{2}$ are left and right fuzziness coefficients. Then parameters of fuzzy numbers $C_{L R}=A_{L R}+B_{L R}=\langle a, \alpha, \beta\rangle, C_{L R}=A_{L R} \cdot B_{L R}=\langle a, \alpha, \beta\rangle$ and $C_{L R}=q A_{L R}=\langle a, \alpha, \beta\rangle$ are calculated using the following formulae:

$$
\begin{gathered}
a=a_{1}+a_{2}, \alpha=\alpha_{1}+\alpha_{2}, \beta=\beta_{1}+\beta_{2} ; \\
a=a_{1} a_{2}, \alpha=a_{1} \alpha_{2}+a_{2} \alpha_{1}, \beta=a_{1} \beta_{2}+a_{2} \beta_{1} ; \\
a=q a_{1}, \alpha=q \alpha_{1}, \beta=q \beta_{1} .
\end{gathered}
$$


Let us determine the sum of $n$ fuzzy numbers $s=\sum_{i=1}^{n} z_{i}$, for each of which membership function is defined with the formula similar to formula (3). Obviously, $z_{i}^{(L R)}=\left\langle a_{z i}, \alpha_{z i}, \alpha_{z i}\right\rangle$. Then, $s_{1.2}=z_{1}+z_{2}$. According to formula (5), $s_{1.2 .}^{(L R)}=\left\langle a_{1.2}, \alpha_{1.2 .}, \alpha_{1 . .2}\right\rangle$, where $a_{1.22}=a_{z 1}+a_{z 2}, \alpha_{1.22}=\alpha_{z 1}+\alpha_{z 2}$.

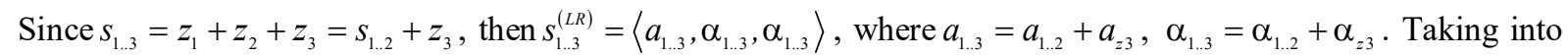
account the values of $a_{1.2}$ and $\alpha_{1.2 .}$, we obtain $a_{1.3}=a_{z 1}+a_{z 2}+a_{z 3}$ and $\alpha_{1.33}=\alpha_{z 1}+\alpha_{z 2}+\alpha_{z 3}$. In a general case, continuing this iteration process will result in the equation $s_{L R}=\left\langle a_{s}, \alpha_{s}, \alpha_{s}\right\rangle$, where

$$
a_{s}=\sum_{i=1}^{n} a_{z i}, \alpha_{s}=\sum_{i=1}^{n} \alpha_{z i}
$$

Using formula (6), it can be shown that if $s=\sum_{i=1}^{n} c_{i} z_{i}$, then $s_{L R}=\left\langle a_{s}, \alpha_{s}, \alpha_{s}\right\rangle$, where

$$
a_{s}=\sum_{i=1}^{n} c_{i} a_{z i}, \alpha_{s}=\sum_{i=1}^{n} c_{i} \alpha_{z i}
$$

For the product of $m$ fuzzy numbers $V=\prod_{i=1}^{m} z_{i}$, where $z_{i}^{(L R)}=\left\langle a_{z i,}, \alpha_{z i}, \alpha_{z i}\right\rangle, \quad V_{1.2}=z_{1} z_{2}$. Let us define parameters of the fuzzy variable $V_{1.22}^{(L R)}=\left\langle a_{1.2 .}, \alpha_{1 . .2}, \alpha_{1.22}\right\rangle$. According to the formulae (7), $a_{1.22}=a_{z 1} a_{z 2}$ and $\alpha_{1.2}=a_{z 1} \alpha_{z 2}+a_{z 2} \alpha_{z 1}$. Then we can write down that $V_{1.3}=z_{1} z_{2} z_{3}=V_{1.2} z_{3}$, and $V_{1.3}^{(L R)}=\left\langle a_{1.3}, \alpha_{1.3 .3}, \alpha_{1.3}\right\rangle$, respectively. We find that $a_{1.3}=a_{1.2} a_{3}$ and $\alpha_{1.3}=a_{1.2} \alpha_{3}+a_{3} \alpha_{1.2 .}$. Taking into account the equations for $a_{1.2}$ and $\alpha_{1.22}$, we obtain $a_{1.33}=a_{z 1} a_{z 2} a_{z 3}$ and $\alpha_{1 . .3}=a_{z 1} a_{z 2} \alpha_{z 3}+a_{z 3}\left(a_{z 1} \alpha_{z 2}+a_{z 2} \alpha_{z 1}\right)=a_{z 1} a_{z 2} \alpha_{z 3}+a_{z 1} a_{z 3} \alpha_{z 2}+a_{z 2} a_{z 3} \alpha_{z 1}$. Since $V_{1.4}=V_{1.3} z_{4}$ and $V_{1.4}^{(L R)}=\left\langle a_{1.4}, \alpha_{1.4}, \alpha_{1.4 .}\right\rangle$, then according to (7), $a_{1.4}=a_{1.3 .3} a_{z 4}$ and $\alpha_{1.4}=a_{1.3 .3} \alpha_{z 4}+a_{z 4} \alpha_{1.3 .}$. If the previously defined $a_{1.2}$ and $\alpha_{1.2}$ are taken into consideration, then $a_{1.4}=a_{z 1} a_{z 2} a_{z 3} a_{z 4}$ and $\alpha_{1.4}=a_{z 1} a_{z 2} a_{z 3} \alpha_{z 4}+a_{z 4}\left(a_{z 1} a_{z 2} \alpha_{z 3}+a_{z 1} a_{z 3} \alpha_{z 2}+a_{z 2} a_{z 3} \alpha_{z 1}\right)==a_{z 1} a_{z 2} a_{z 4} \alpha_{z 3}+a_{z 1} a_{z 3} a_{z 4} \alpha_{z 2}+a_{z 2} a_{z 3} a_{z 4} \alpha_{z 1}$.

Summarizing the obtained result, we arrive at the conclusion that $V_{L R}=\left\langle a_{V}, \alpha_{V}, \alpha_{V}\right\rangle$, where

$$
a_{V}=\prod_{i=1}^{m} a_{z i}, \quad \alpha_{V}=\sum_{i=1}^{m} \alpha_{z i} \prod_{\substack{k=1, k \neq i}}^{m} a_{z k} .
$$

Using formula (10), the degree of $(L-R)$ type fuzzy number can be found. If $z_{1}=z_{2}=\cdots=z_{m}=z$, then $V=z^{m}$ and $V_{L R}=\left\langle a_{V}, \alpha_{V}, \alpha_{V}\right\rangle$. Therefore,

$$
a_{V}=a_{z}^{m}, \alpha_{V}=m \alpha_{z} a_{z}^{m-1}, m \geq 2 .
$$

The obtained results enable finding membership function $\mu(y)$ of output variable $y$. Let us designate $z_{j}=\prod_{i=1}^{m} x_{i}^{\varphi_{j i}}$. Then model (1) will be represented by $y=\sum_{j=0}^{n} c_{j} z_{j}$ and $y_{L R}=\left\langle a_{y}, \alpha_{y}, \alpha_{y}\right\rangle$. According to 
formulae (10), $a_{y}=\sum_{j=0}^{n} c_{j} a_{z j}$ and $\alpha_{y}=\sum_{j=0}^{n} c_{j} \alpha_{z j}$. Now let us find expressions for $a_{z j}$ and $\alpha_{z j}$, for which we introduce another fuzzy variable $p_{i}(j)=x_{i}^{\varphi_{i j}}$ and $p_{i}^{(L R)}(j)=\left\langle a_{p i}(j), \alpha_{p i}(j), \alpha_{p i}(j)\right\rangle$. Then, $z_{j}=\prod_{i=1}^{m} p_{i}(j)$. In correspondence with formulae (10),

$$
a_{z j}=\prod_{i=1}^{m} a_{p i}(j) \text { and } \alpha_{z j}=\sum_{i=1}^{m} \alpha_{p i}(j) \prod_{\substack{k=1, k \neq i}}^{m} a_{p k}(j)
$$

In view of the fact that $p_{i}(j)=x_{i}^{\varphi_{i j}}$ and $x_{i}^{(L R)}=\left\langle x_{i}^{(0)}, \alpha_{x i}, \alpha_{x i}\right\rangle, i=\overline{1, m}$, then according to formulae (11), $a_{p i}(j)=\left(x_{i}^{(0)}\right)^{\varphi_{j i}}, a_{p k}(j)=\left(x_{i}^{(0)}\right)^{\varphi_{j k}}$ and $\alpha_{p i}(j)=\varphi_{j i}\left(x_{i}^{(0)}\right)^{\varphi_{j i}-1} \alpha_{x i}$. Inserting the obtained results into formulae (12) will result in $a_{z j}=\prod_{i=1}^{m}\left(x_{i}^{(0)}\right)^{\varphi_{j i}}$ and $\alpha_{z j}=\sum_{i=1}^{m} \varphi_{j i}\left(x_{i}^{(0)}\right)^{\varphi_{i j}-1} \alpha_{x i} \prod_{\substack{k=1 \\ k \neq i}}^{m}\left(x_{i}^{(0)}\right)^{\varphi_{j, k}}$. Since $a_{z j}$ and $\alpha_{z j}$ are defined, we will obtain

$$
a_{y}=\sum_{j=0}^{n} c_{j} \prod_{k=1}^{m}\left(x_{i}^{(0)}\right)^{\varphi_{j k}}, \alpha_{y}=\sum_{j=0}^{n} c_{j}\left(\sum_{i=1}^{m} \varphi_{j i}\left(x_{i}^{(0)}\right)^{\varphi_{i j}-1} \alpha_{x i} \prod_{\substack{k=1, k \neq i}}^{m}\left(x_{i}^{(0)}\right)^{\varphi_{j k}}\right) .
$$

A next step will be to define $\gamma$-slice for membership function (4). Then, $\exp \left(-\frac{\left(y-a_{y}\right)^{2}}{2 \alpha_{y}^{2}}\right)=\gamma$.

From the previous equation we derive

$$
y=a_{y}+\alpha_{y} \sqrt{\ln \frac{1}{\gamma^{2}}} .
$$

Inserting $a_{y}$ and $\alpha_{y}$ from (13) into formula (14) will result in the following expression:

$$
y=\sum_{j=0}^{n} c_{j}\left(\prod_{i=1}^{m}\left(x_{i}^{(0)}\right)^{\varphi_{j k}}+A_{\gamma}\left(\sum_{i=1}^{m} \varphi_{j i}\left(x_{i}^{(0)}\right)^{\varphi_{i j}-1} \alpha_{x i} \prod_{\substack{k=1, k \neq i}}^{m}\left(x_{k}^{(0)}\right)^{\varphi_{j k}}\right)\right),
$$

where $A_{\gamma}=\sqrt{\ln \frac{1}{\gamma^{2}}}$.

This result suggests that taking into consideration fuzziness of input data causes a certain "penalty", the value of which is determined by the parameters of membership function (3).

Now the task of fuzzy identification can be restated - to determine the parameters $c_{j}, j=\overline{0, n-1}$ of the model (15) so as to minimize sum of squared deviations of calculated values defined by expression (15) from the output values

$$
J(\bar{c})=\sum_{t=1}^{N}\left(Y_{t}-y_{t}\right)^{2}
$$

where $y_{t}$ is calculated output value for each observation point. 
Let us assume that observation covers input variables $x_{i}^{(0)}$ designated by $x_{i}, i=\overline{1, m}$ and form a matrix

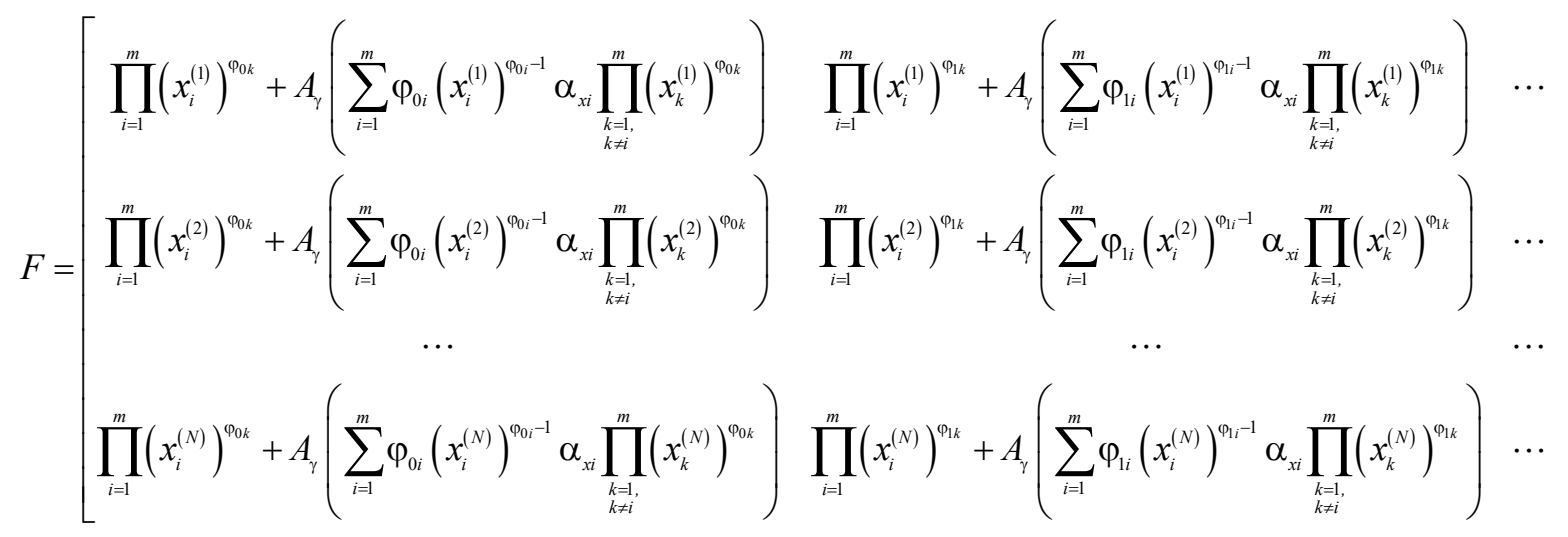

$$
\begin{aligned}
& \left.\cdots \quad \prod_{i=1}^{m}\left(x_{i}^{(1)}\right)^{\varphi_{p h k}}+A_{\gamma}\left(\sum_{i=1}^{m} \varphi_{n i}\left(x_{i}^{(1)}\right)^{\varphi_{n i}-1} \alpha_{x i} \prod_{\substack{k=1 \\
k \neq i}}^{m}\left(x_{k}^{(1)}\right)^{\varphi_{p k k}}\right)\right] \\
& \cdots \quad \prod_{i=1}^{m}\left(x_{i}^{(2)}\right)^{\varphi_{n k}}+A_{\gamma}\left(\sum_{i=1}^{m} \varphi_{n i}\left(x_{i}^{(2)}\right)^{\varphi_{m}-1} \alpha_{x i} \prod_{\substack{k=1,1 \\
k \neq i}}^{m}\left(x_{k}^{(2)}\right)^{\varphi_{n k}}\right) \text {. } \\
& \left.\cdots \quad \prod_{i=1}^{m}\left(x_{i}^{(N)}\right)^{\varphi_{n k}}+A_{\gamma}\left(\sum_{i=1}^{m} \varphi_{n i}\left(x_{i}^{(N)}\right)^{\varphi_{n i n}-1} \alpha_{x i} \prod_{\substack{k=1 \\
k \neq i}}^{m}\left(x_{k}^{(N)}\right)^{\varphi_{n k}}\right)\right]
\end{aligned}
$$

Consequently, $\bar{y}=F \bar{c}$ and functional (15) will be expressed as follows:

$$
J(\bar{c})=(\bar{Y}-\bar{y})^{T}(\bar{Y}-\bar{y})
$$

where $\bar{Y}=\left(Y_{1}, Y_{2}, \ldots, Y_{N}\right)^{T}$ is output value vector in every observation point $t=\overline{1, N} ; \bar{y}=\left(y_{1}, y_{2}, \ldots, y_{N}\right)^{T}$ is the vector of output values calculated by equation (15) in every observation point.

Minimization of functional (17) with respect to vector-variable $\bar{c}$ results in $\bar{c}=M^{-1} F^{T} \bar{Y}$ [10], where $M=F^{T} F$ is a Fisher matrix.

Let us assume that the relationship between the input and output of an object is described by expression (1), and $m=2, r=2$. The number of terms of this regression dependence can be calculated using formula (2) $-n=6$.

As a next step, we designate:

$$
f\left(\bar{x}, \varphi_{j i}\right)=\sum_{i=1}^{m} \varphi_{j i}\left(x_{i}^{(0)}\right)^{\varphi_{j i j}-1} \alpha_{x i} \prod_{\substack{k=1 \\ k \neq i}}^{m}\left(x_{k}^{(0)}\right)^{\varphi_{j k}}
$$

Then we form a matrix of degrees of regression model (1)

$$
\Phi^{T}=\left[\begin{array}{llllll}
\varphi_{01} & \varphi_{11} & \varphi_{21} & \varphi_{31} & \varphi_{41} & \varphi_{51} \\
\varphi_{02} & \varphi_{12} & \varphi_{22} & \varphi_{32} & \varphi_{42} & \varphi_{52}
\end{array}\right]=\left[\begin{array}{llllll}
0 & 1 & 0 & 1 & 2 & 0 \\
0 & 0 & 1 & 1 & 0 & 2
\end{array}\right] .
$$

Let us calculate $f\left(\bar{x}, \varphi_{0 i}\right)=\varphi_{01} x_{1}^{\varphi_{01}-1} \alpha_{1} x_{2}^{\varphi_{02}}+\varphi_{02} x_{2}^{\varphi_{02}-1} \alpha_{2} x_{1}^{\varphi_{01}}$. Using values of $\varphi_{01}$ and $\varphi_{02}$, we obtain $f\left(\bar{x}, \varphi_{0 i}\right)=0$. 
Similarly, we find that

$$
\begin{aligned}
& f\left(\bar{x}, \varphi_{1 i}\right)=\varphi_{11} x_{1}^{\varphi_{11}-1} \alpha_{x 1} x_{2}^{\varphi_{12}}+\varphi_{12} x_{2}^{\varphi_{12}-1} \alpha_{x 2} x_{1}^{\varphi_{11}}=\alpha_{x 1}, \\
& f\left(\bar{x}, \varphi_{2 i}\right)=\varphi_{21} x_{1}^{\varphi_{21}-1} \alpha_{x 1} x_{2}^{\varphi_{22}}+\varphi_{22} x_{2}^{\varphi_{22}-1} \alpha_{x 2} x_{1}^{\varphi_{21}}=\alpha_{x 2}, \\
& f\left(\bar{x}, \varphi_{3 i}\right)=\varphi_{31} x_{1}^{\varphi_{31}-1} \alpha_{x 1} x_{2}^{\varphi_{32}}+\varphi_{32} x_{2}^{\varphi_{32}-1} \alpha_{x 2} x_{1}^{\varphi_{31}}=\alpha_{x 1} x_{2}+\alpha_{x 2} x_{1}, \\
& f\left(\bar{x}, \varphi_{4 i}\right)=\varphi_{41} x_{1}^{\varphi_{41}-1} \alpha_{x 1} x_{2}^{\varphi_{42}}+\varphi_{42} x_{2}^{\varphi_{42}-1} \alpha_{x 2} x_{1}^{\varphi_{41}}=2 \alpha_{x 1} x_{1}, \\
& f\left(\bar{x}, \varphi_{5 i}\right)=\varphi_{51} x_{1}^{\varphi_{51}-1} \alpha_{x 1} x_{2}^{\varphi_{52}}+\varphi_{52} x_{2}^{\varphi_{52}-1} \alpha_{x 2} x_{1}^{\varphi_{51}}=2 \alpha_{x 2} x_{2} .
\end{aligned}
$$

Therefore, taking aboard the fuzziness of input variables, the output of the object $(m=2, r=2)$ will be represented by the empirical relationship as follows:

$$
\begin{aligned}
& y=c_{0}+c_{1}\left(x_{1}+A_{\gamma} \alpha_{x 1}\right)+c_{2}\left(x_{2}+A_{\gamma} \alpha_{x 2}\right)+c_{3}\left(x_{1} x_{2}+A_{\gamma}\left(x_{1} \alpha_{x 2}+x_{2} \alpha_{x 1}\right)\right)+ \\
& +c_{4}\left(x_{1}^{2}+2 A_{\gamma} \alpha_{x 1} x_{1}\right)+c_{5}\left(x_{2}^{2}+2 A_{\gamma} \alpha_{x 2} x_{2}\right) .
\end{aligned}
$$

If $\gamma=1$, then $A_{\gamma}=0$, and we come to a well-defined identification task in which mode values of the input variable are equated with their directly observable values.

\section{Conclusions}

There was developed a method of constructing a polynomial empirical model, assuming that input factors are fuzzy variables with the defined Gaussian membership function. It was shown that the obtained empirical model is also a polynomial in which an input factor has an additional component as a "penalty" for fuzziness of input data. The least square method was applied to find the parameters of the fuzzy empirical model.

\section{References}

[1] Ivakhnenko A. G. Simulation of interference stability: monograph / A. G. Ivakhnenko, V. S. Stepashko. - Kyiv : Naukova Dumka, 1985. 216 p. (in Russian)

[2] Ivakhnenko A. G. Inductive method of self organization of complicated systems models : monograph / A. G. Ivakhnenko - Kyiv : Naukova Dumka, 1981. - 296 p. (in Russian)

[3] Ivakhnenko A. G. Handbook on typical programs for simulation / A. G. Ivakhnenko, Y. V. Koppa, V. S. Stepashko et al. ; under edition of A. G. Ivakhnenko - Kyiv : Tekhnika, 1980. - 180 p. (in Russian)

[4] Gorbiychuk M. I. Method of synthesis of empirical models based on the genetic algorithms / M. I. Gorbiychuk, M. I. Kohutyak, O. B. Vasylenko, I. V. Shchupak // Exploration and development of oil and gas fields. - 2009. - No 4 (33). - P. 72-79. (in Ukrainian)

[5] Gorbiychuk M. I. Method of synthesis of empirical models with taking into account the measurement errors / M. I. Gorbiychuk, I. V. Shchupak, T. Oskolip // Methods and devices of quality control. - 2011. - No 2 (27). - P. 67-76. (in Ukrainian)

[6] Demin D. A. Linear regression analysis of a small sample of fuzzy initial data / D. A. Demin, O. V. Seraya // International scientific and engineering journal "Problems of control and automatics" - 2012. - No 4. - P. 129-142. (in Russian)

[7] Gorbiychuk M. I. Inductive method of building the mathematical models of natural gas pumping facilities / M. I. Gorbiychuk, M. I. Kohutyak, Y. I. Zayachuk // Oil and gas industry. - 2008. - No 5. - P. 32-35. (in Ukrainian)

[8] Dubois D. The theory of possibilities. Appendix to knowledge representation in computer science; translated from French / D. Dubois, A. Prad - Moscow : Radio and Communications, 1990. - 286 p. (in Russian)

[9] Raskin L. G. Fuzzy mathematics. Basics of theory. Appendixes / L. G. Raskin, O. V. Seraya. - Kharkiv : Parus, $2008 .-352$ p. (in Russian)

[10] Ermakov S. M. Mathematical theory of optimal experiment / S. M. Ermakov, A. A. Zhiglavskiy - Moscow : Nauka, $1987 .-280$ p. (in Russian) 


\title{
Нечітка ідентифікація технологічних об'єктів
}

\author{
Михайло Горбійчук, Тарас Гуменюк, Дмитро Поварчук \\ Івано-Франківський національний технічний університет нафти і газу, \\ вул. Карпатська, 15, \\ м. Івано-Франківськ, 76019, Україна
}

\begin{abstract}
Анотація
На практиці інформація про статистичні характеристики адитивної перешкоди є доступною лише в окремих випадках. Більш того, вхідні величини з тих чи інших причин вимірюються неточно і їхні значення можна вказати 3 деякою непевністю. Задача ідентифікація значно ускладнюється у тих випадках, коли вимірювальний сигнал проходить через природний канал з невідомими статистичними характеристиками. Така ситуація трапляється, наприклад, під час буріння свердловин, коли осьове навантаження на долото $\mathrm{i}$ частота його обертання вимірюються наземними приладами. Розроблено метод побудови емпіричних моделей поліноміального вигляду для випадку, коли вхідні фактори є нечіткими величинами з відомими функціями належності гаусового типу. Показано, що за таких умов вихідна величина моделі $є$ також нечіткою величиною та отримана відповідна функція належності, яка $\epsilon$ основою для формування задачі ідентифікації. Для визначення параметрів моделі з нечіткими вхідними факторами використано метод найменших квадратів, що дало змогу отримати відповідну формулу, у структуру якої входить інформація про нечіткість вхідних факторів.
\end{abstract}

Ключові слова: модель; поліноміальна залежність; функція належності; нечіткі числа; метод; параметри моделі. 